\title{
FUZZY LOGIC METODE MAMDANI UNTUK MEMBANTU DIAGNOSA DINI AUTISM SPECTRUM DISORDER
}

\author{
Fithriani Matondang ${ }^{1}$, Ririen Kusumawati ${ }^{2}$, Zainal Abidin ${ }^{3}$ \\ Jurusan Teknik Informatika, Sains dan Teknologi \\ Universitas Islam Negeri (UIN) Maulana Malik Ibrahim Malang \\ 1fiael_mirala@yahoo.com, ${ }^{3}$ br52s@yahoo.com
}

\begin{abstract}
Abstrak - Autism Spectrum Disorder (autis) merupakan gangguan yang dimulai dan dialami pada masa kanak-kanak, yang membuat dirinya tidak dapat membentuk hubungan sosial atau komunikasi yang normal, akibatnya anak tersebut terisolasi dari manusia lain. Perkembangan yang terganggu terutama dalam komunikasi, interaksi sosial dan perilaku. Namun permasalahan yang muncul adalah bagaimana cara mengetahui seorang anak menderita autis atau tidak, begitu juga cara penanganannya yang optimal. Seiring dengan kemajuan teknologi saat ini, berbagai permasalahan yang ada dapat diselesaikan dengan memanfaatkan teknologi. Salah satunya dengan membangun aplikasi sistem pakar untuk mendiagnosa Autism Spectrum Disorder (ASD) dengan fuzzy logic. Input sistem adalah gejala autis, sedangkan output sistem adalah Anak Normal (bukan autis) dan Anak Autis. Proses perhitungan sistem dilakukan dengan 4 tahapan mamdani yaitu: Pembentukan himpunan fuzzy, Implikasi aturan, Komposisi aturan dan Defuzzyfikasi. Dari hasil uji coba sistem, diperoleh data error sebanyak 40 data dari 1287 data uji coba jika dibandingkan dengan hasil uji coba manual. Dari hasil perbandingan uji coba tersebut, diperoleh persentase Error sebanyak 3.11 \%, Recall sebesar 69\%, dan Presisi sebesar 99\%.
\end{abstract}

Kata Kunci : Autism Spectrum Disorder, Fuzzy Logic, Gejala Autis , Mamdani

\section{PENDAHULUAN}

Semua orang tua pasti menginginkan anaknya lahir dengan selamat dan normal, baik secara fisik, perilaku, maupun mental. Akan tetapi dalam kenyataannya terdapat dua jenis anak, yaitu anak normal dan anak berkebutuhan khusus yang keduanya memiliki hak yang sama dalam memperoleh pendidikan. Anak berkebutuhan khusus misalnya autis juga memiliki hak dalam mengembangkan diri, kedudukan dan memperoleh pendidikan. Lazimnya seperti halnya gejala autis dan hiperaktif yang sering terjadi pada anakanak. Tidak mudah ketika orang tua harus berhadapan dengan kondisi anak yang seperti ini. Hal ini tentunya diperlukan penanganan khusus mengingat keadaan yang ada pada anak tersebut.

Jika anaknya terkena autis, ibu akan sangat gugup karena tak fokus, cenderung pendiam dan sulit untuk beradaptasi. Karena itu sangat penting bagi kaum ibu untuk mengerti dan memahami gangguan autis, sehingga jika suatu saat anaknya mengalami gangguan seperti gejala tersebut, anaknya bisa ditangani dengan tepat dan benar.

Tujuan penelitian ini adalah membantu diagnosa dini Autism Spectrum Disorder (ASD) dengan fuzzy logic menggunakan metode mamdani.

\section{DASAR TEORI}

\subsection{Fuzzy Logic}

Sebelum munculnya teori fuzzy (fuzzy logic), dikenal sebuah logika tegas (Crisp logic) yang memiliki nilai benar atau salah secara tegas. Sebaliknya logika fuzzy merupakan sebuah logika yang memiliki nilai kekaburan atau kesamaran antara benar dan salah. Dalam teori logika fuzzy 
sebuah nilai bisa bernilai benar dan salah secara bersamaan namun berapa besar kebenaran dan kesalahan suatu nilai tergantung kepada bobot keanggotaan yang dimilikinya.

Kata Fuzzy merupakan kata sifat yang berarti kabur, tidak jelas. Fuzziness atau kekaburan atau ketidakjelasan atau ketidakpastian selalu meliputi keseharian manusia. Logika fuzzy dikatakan sebagai logika baru yang lama, sebab ilmu tentang logika fuzzy modern dan metodis baru ditemukan beberapa tahun yang lalu, padahal sebenarnya konsep tentang logika fuzzy itu sendiri sudah ada sejak lama (Kusumadewi, 2003).

\subsection{Mamdani}

Metode Mamdani sering juga dikenal dengan nama Metode Max-Min. Metode ini diperkenalkan oleh Ebrahim Mamdani pada tahun 1975.Untuk mendapatkan output, diperlukan 4 tahapan:

a. Pembentukan himpunan fuzzy. Pada proses fuzzifikasi langkah yang pertama adalah menentukan variable fuzzy dan himpunan fuzzinya. Kemudian tentukan derajat kesepadanan (degree of match) antara data masukan fuzzy dengan himpunan fuzzy yang telah didefenisikan untuk setiap variabel masukan sistem dari setiap aturan fuzzy. Pada metode mamdani, baik variabel input maupun variabel output dibagi menjadi satu atau lebih himpunan fuzzy.

b. Aplikasi fungsi implikasi pada metode mamdani. Fungsi implikasi yang digunakan adalah min. Lakukan implikasi fuzzy berdasar pada kuat penyulutan dan himpunan fuzzy terdefinisi untuk setiap variabel keluaran di dalam bagian konsekuensi dari setiap aturan. Hasil implikasi fuzzy dari setiap aturan ini kemudian digabungkan untuk menghasilkan keluaran infrensi fuzzy. (Kusumadewi, 2003). c. Komposisi Aturan. Tidak seperti penalaran monoton, apabila sistem terdiri dari beberapa aturan, maka infrensi diperoleh dari kumpulan dan korelasi antar aturan. Ada 3 metode yang digunakan dalam melakukan inferensi sistem fuzzy, yaitu: max, additive dan probabilistik OR.

d. Penegasan (defuzzy). Input dari proses defuzzifikasi adalah suatu himpunan fuzzy yang diperoleh dari komposisi aturan-aturan fuzzy, sedangkan output yang dihasilkan merupakan suatu bilangan pada domain himpunan fuzzy tersebut.

\subsection{Autism Spectrum Disorder (Asd)}

Autis berasal dari kata auto yang berarti sendiri. Penyandang autis seakan-akan hidup di dunianya sendiri. Istilah autisme sudah cukup populer di kalangan masyarakat, karena banyak media massa dan elektronik yang mencoba untuk mengupasnya secara mendalam. Muncul juga banyak keprihatinan atas masalah ini dan akhir-akhir ini kasus autisme menunjukkan peningkatan persentasenya di Indonesia. Autisme merupakan gangguan yang dimulai dan dialami pada masa kanak-kanak. Autisme pertama kali ditemukan oleh Kanner pada tahun 1943. Autisme juga dapat diartikan sebagai suatu kondisi mengenai seseorang sejak lahir ataupun sejak balita, yang membuat dirinya tidak dapat membentuk hubungan sosial atau komunikasi yang normal. Akibatnya anak tersebut terisolasi dari manusia lain dan masuk dalam dunia repetitive, aktivitas dan minat yang obsesif. (Maulana, 2007).

Secara detail, menurut DSM- IV (Diagnostik and Statistical manual of Mental Disorder) 1994, yang dibuat oleh grup psikiatri dari Amerika), kriteria gangguan autistik adalah sebagai berikut (Handojo, 2002):

a) Harus ada sedikitnya 6 gejala dari kelemahan kwalitatif dalam bidang interaksi sosial, kelemahan kwalitatif 
dalam bidang komunikasi dan pola perilaku, dengan minimal 2 gejala dari kelemahan kwalitatif dalam bidang interaksi sosial dan masing-masing 1 gejala dari kelemahan kwalitatif dalam bidang komunikasi dan pola perilaku.

b) Kelemahan kwalitatif dalam interaksi sosial, yang termanifestasi dalam sedikitnya 2 dari beberapa gejala berikut: (1) Kelemahan dalam penggunaan perilaku nonverbal, seperti kontak mata, ekspresi wajah, sikap tubuh, gerak tangan dalam interaksi sosial, (2) Kegagalan dalam mengembangkan hubungan dengan teman sebaya sesuai dengan tingkat perkembangannya, (3) Kurangnya kemampuan untuk berbagi perasaan dan empati dengan orang lain, (4) Kurang mampu mengadakan hubungan sosial dan emosional yang timbal balik.

c) Kelemahan kualitatif dalam bidang komunikasi. Minimal harus ada 1 dari gejala berikut ini: (1) Perkembangan bahasa lisan (bicara) terlambat atau sama sekali tidak berkembang dan anak tidak mencari jalan untuk berkomunikasi secara non verbal, (2) Bila anak bisa bicara, maka bicaranya tidak digunakan untuk berkomunikasi, (3) Sering menggunakan bahasa yang aneh, stereotype dan berulangulang. (4) Kurang mampu bermain imajinatif (make believe play) atau permainan imitasi sosial lainnya sesuai dengan taraf perkembangannya.

d) Pola perilaku serta minat dan kegiatan yang terbatas, berulang. Minimal harus ada 1 dari gejala berikut ini : (1) Preokupasi terhadap satu atau lebih kegiatan dengan fokus dan intensitas yang abnormal/ berlebihan, (2) Terpaku pada suatu kegiatan ritualistik atau rutinitas, (3) Gerakan-gerakan fisik yang aneh dan berulang-ulang seperti menggerak-gerakkan tangan, bertepuk tangan, menggerakkan tubuh, (4) Sikap tertarik yang sangat kuat/ preokupasi dengan bagian-bagian tertentu dari objek.

e) Keterlambatan atau abnormalitas muncul sebelum usia 3 tahun minimal pada salah satu bidang berikut: (1) interaksi sosial, (2) kemampuan bahasa dan komunikasi, (3) cara bermain simbolik dan imajinatif.

\section{METODOLOGI}

\subsection{Himpunan Fuzzy}

Variabel fuzzy yang digunakan terdiri dari Gejala Interaksi Sosial (I), Gejala Komunikasi (K), Gejala Perilaku (P), dan Jumlah gejala (A). Sedangkan himpunan Fuzzy dari setiap variabel keanggotaan yaitu Sedikit dan Banyak. Dimana keanggotaan Sedikit pada variabel I bernilai dua, dan keanggotaan Banyak bernilai duabelas, variabel $\mathrm{K}$ keanggotaan Sedikit bernilai satu dan keanggotaan Banyak bernilai sepuluh, variabel $P$ keanggotaan Sedikit bernilai satu dan keanggotaan Banyak bernilai delapan.

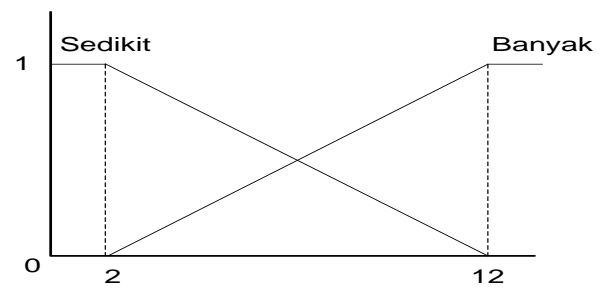

Gambar 1. Himpunan Fuzzy Variabel I.

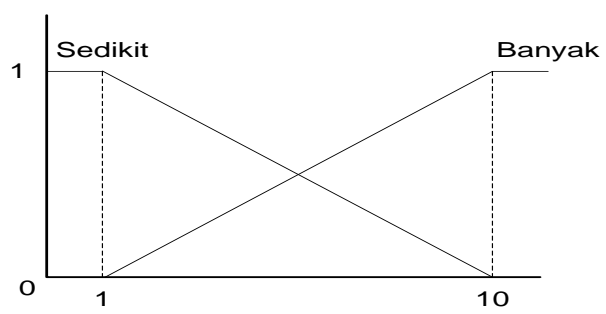

Gambar 2. Himpunan Fuzzy Variabel K.

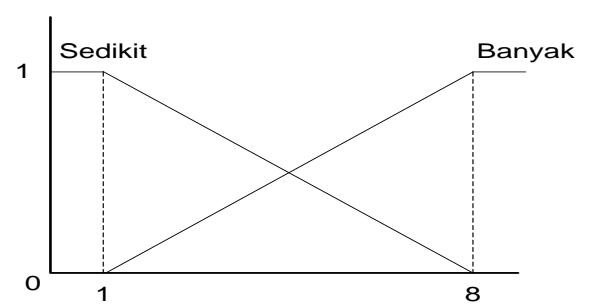

Gambar 3. Himpunan Fuzzy Variabel P. 


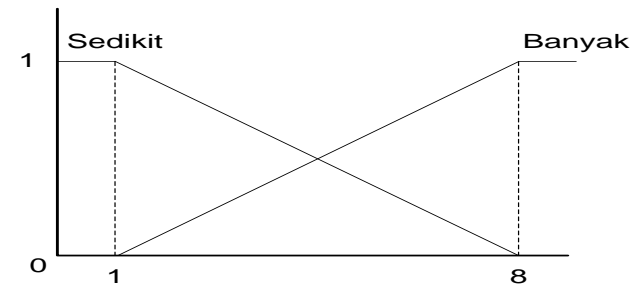

Gambar 4. Himpunan Fuzzy Variabel A.

\subsection{Aturan Fuzzy}

Untuk mendiagnosa seorang anak menderita autis atau bukan, fuzzy memiliki 8 aturan yang diperoleh dari kombinasi jumlah variabel input (3) dan output (2) dengan rumus: noutput ${ }^{\text {ninput }}=2^{3}=8$. Aturan fuzzy dapat dilihat pada Tabel 1.

\subsection{Proses Mamdani}

Proses mamdani meliputi tahap fuzzifikasi, fungsi implikasi (Min), komposisi aturan dan defuzzifikasi. Pada tahap fuzzifikasi, fungsi keanggotaan setiap himpunan ditentukan berdasarkan nilai $x$ yang ditentukan. Tahap Fungsi Implikasi, diperoleh dengan mengambil nilai Min dari seluruh nilai fungsi keanggotaan setiap himpunan berdasarkan rule (aturan) yang telah ditetapkan. Sedangkan tahap Komposisi Aturan, diperoleh dengan menentukan luasan daerah dari fungsi implikasi aturan dengan mengambil nilai Max, kemudian tahap Fuzzifikasi, ditentukan dengan menghitung jumlah nilai $\mathrm{z}$ dari luasan daerah dibagi dengan nilai predikat setiap implikasi aturan.

Untuk menentukan batas minimal dan maksimal autis, dilakukan percobaan terhadap semua nilai $x$ untuk $\mathrm{I}+\mathrm{K}+\mathrm{P}=6$. Gejala minimal autis dapat dilihat pada Tabel 2. Nilai tertinggi pada data gejala

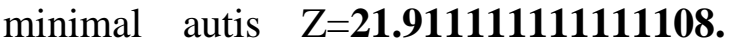
Dengan demikian, dapat ditentukan batas minimal/maksimal autis dan normal yaitu: $Z<=21.911111111111108$ (Autis) $Z>21.911111111111108$ (Normal).

Berikut ini diberikan satu contoh kasus menggunakan perhitungan fuzzy mamdani:
Firman adalah anak laki-laki berusia 4 tahun. Firman memiliki gangguan dalam perkembangannya, sebagai berikut:

a. Tidak mengambil giliran ketika bermain permainan sederhana dengan orang lain

b. Menghindari kontak mata atau seolaholah melihat orang lain

c. Sering menggunakan bahasa yang aneh dan diulang-ulang

d. Tidak mampu menunjuk anggota tubuh atau benda-benda yang umum bila ditanya

e. Melambaikan, memutar jari tangan didepan wajah.

f. Membawa karet kemana-mana

g. Menyukai objek yang berputar, memutar botol, roda mainan

Dari gejala yang dialami firman, apakah firman dapat diduga anak autis atau bukan?

Setelah diteliti ternyata firman memiliki gangguan dalam interaksi sosial sebanyak dua gejala (Tidak mengambil giliran ketika bermain permainan sederhana dengan orang lain, menghindari kontak mata atau seolah-olah melihat orang lain), gangguan dalam perkembangan komunikasi sebanyak dua gejala (Sering menggunakan bahasa yang aneh dan diulang-ulang, tidak mampu menunjuk anggota tubuh atau benda-benda yang umum bila ditanya) dan gangguan dalam perilaku sebanyak tiga gejala (Melambaikan, memutar jari tangan didepan wajah. membawa karet kemanamana, menyukai objek yang berputar, memutar botol, roda mainan).

Seperti ketentuan Mamdani, tahap yang pertama adalah mencari fungsi keanggotaan untuk setiap himpunan fuzzy pada variabel I,K,P: $\quad \mu$ Sedikit[I], $\mu$ Banyak[I], $\mu$ Sedikit[K], $\mu \operatorname{Banyak}[\mathrm{K}]$, $\mu$ Sedikit $[\mathrm{P}]$, dan $\mu$ Banyak[P]. Setelah nilai fungsi keanggotaan ditemukan, fungsi implikasi aturan (rule) ditentukan dengan mengambil nilai minimum dari nilai keanggotaan. Untuk proses perhitungan 
fuzzy mamdani pada contoh kasus tersebut data dilihat pada Gambar 5.

\subsection{Uji Coba}

Untuk mengetahui seorang anak autis atau tidak, diagnosa autis memiliki kriteria sebagai berikut: Harus ada sedikitnya 6 gejala dari kelemahan kwalitatif dalam bidang Interaksi Sosial (I), kelemahan kwalitatif dalam bidang Komunikasi (K) dan pola Perilaku (A), dengan minimal 2 gejala dari kelemahan kwalitatif dalam bidang Interaksi Sosial dan masing-masing 1 gejala dari kelemahan kwalitatif dalam bidang Komunikasi dan pola Perilaku. Untuk I Min=2, I Max=12, K Min=1, K Max $=10$ dan $P$ Min=1, $P$ Max $=8$.

Tabel 1. Aturan Fuzzy

\begin{tabular}{|c|c|c|}
\hline Kode & Aturan & Konsekuen \\
\hline [R1] & $\begin{array}{l}\text { If I sedikit and } \mathrm{K} \\
\text { sedikit and P } \\
\text { sedikit then }\end{array}$ & A sedikit \\
\hline [R2] & $\begin{array}{l}\text { If I sedikit and } \mathrm{K} \\
\text { sedikit and P } \\
\text { banyak then }\end{array}$ & A sedikit \\
\hline [R3] & $\begin{array}{l}\text { If I sedikit and } \mathrm{K} \\
\text { banyak and P } \\
\text { sedikit then }\end{array}$ & A sedikit \\
\hline [R4] & $\begin{array}{l}\text { If I sedikit and } \mathrm{K} \\
\text { banyak and } \mathrm{P} \\
\text { banyak then }\end{array}$ & A sedikit \\
\hline [R5] & $\begin{array}{l}\text { If I banyak and } \mathrm{K} \\
\text { sedikit and } \mathrm{P} \\
\text { sedikit then }\end{array}$ & A banyak \\
\hline [R6] & $\begin{array}{l}\text { If I banyak and } \mathrm{K} \\
\text { sedikit and } \mathrm{P} \\
\text { banyak then }\end{array}$ & A banyak \\
\hline [R7] & $\begin{array}{l}\text { If I banyak and K } \\
\text { banyak and P } \\
\text { sedikit then }\end{array}$ & A banyak \\
\hline [R8] & $\begin{array}{l}\text { If I banyak and } \mathrm{K} \\
\text { banyak and } \mathrm{P} \\
\text { banyak then }\end{array}$ & A banyak \\
\hline
\end{tabular}

Untuk mengetahui seberapa besar ketepatan sistem dalam membantu diagnosa autis dengan fuzzy, dilakukan uji coba terhadap semua kemungkinan yang terjadi dari jumlah semua inputan sistem sebanyak 1287 data. Data sejumlah 1287 diperoleh dari kombinasi antara $I, K, P$, $\left(13^{*} 11^{*} 9\right)$, sehingan diperoleh 1287 data. (Lihat persamaan (1)). Kemudian data hasil perhitungan fuzzy dibandingkan dengan data kriteria autis menurut DSMIV .

$$
\sum n I * \sum n K * \sum n P .
$$

Tabel 2. Gejala minimal autis

\begin{tabular}{|c|c|c|c|}
\hline $\mathbf{I}$ & $\mathbf{K}$ & $\mathbf{P}$ & $\mathbf{Z}$ \\
\hline 2 & 2 & 2 & 21.857142857142854 \\
\hline 2 & 3 & 1 & 21.676767676767682 \\
\hline 2 & 1 & 3 & 21.492063492063494 \\
\hline 3 & 1 & 2 & 21.857142857142854 \\
\hline 3 & 2 & 1 & $\mathbf{2 1 . 9 1 1 1 1 1 1 1 1 1 1 1 0 8}$ \\
\hline 4 & 1 & 1 & 21.733333333333334 \\
\hline
\end{tabular}

Interaksi Sosial (2), Komunikasi (2), Perilaku (3)

\section{Fuzzyfikasi}

Fungsi Keanggotaan

uInteraksiBanyak $[2]=0.0$

uInteraksiSedikit[2] $=1.0$

uPerilakuBanyak[3] $=0.2857142857142857$

uPerilakuSedikit [3] $=0.7142857142857143$

uKomunikasiBanyak[2] $=0.1111111111111111$

uKomunikasiSedikit[2] $=0.8888888888888888$

uGejalaAutisBanyak[7] $=0.041666666666666664$

uGejalaAutisSedikit[7] $=0.9583333333333334$

\section{Fungsi Implikasi}

RULE

$\mathrm{R}[1]$ If I sedikit and $\mathrm{K}$ sedikit and $\mathrm{P}$ sedikit then A sedikit

$=0.7142857142857143$

$\mathrm{R}[2]$ If I sedikit and $\mathrm{K}$ sedikit and P banyak then A sedikit

$=0.1111111111111111$

$\mathrm{R}$ [3] If I sedikit and $\mathrm{K}$ banyak and $\mathrm{P}$ sedikit then A sedikit

$=0.2857142857142857$

$\mathrm{R}[4]$ If I sedikit and $\mathrm{K}$ banyak and P banyak then A sedikit

$=0.1111111111111111$

$\mathrm{R}$ [5] If I banyak and $\mathrm{K}$ sedikit and P sedikit then A banyak

$=0.0$

$\mathrm{R}[6]$ If I banyak and K sedikit and P banyak then A banyak

$=0.0$

$\mathrm{R}$ [7] If I banyak and $\mathrm{K}$ banyak and $\mathrm{P}$ sedikit then $\mathrm{A}$ banyak

$=0.0$

$\mathrm{R}[8]$ If I banyak and $\mathrm{K}$ banyak and $\mathrm{P}$ banyak then $\mathrm{A}$ banyak

$=0.0$

$\underline{\text { Komposisi Aturan }}$ 


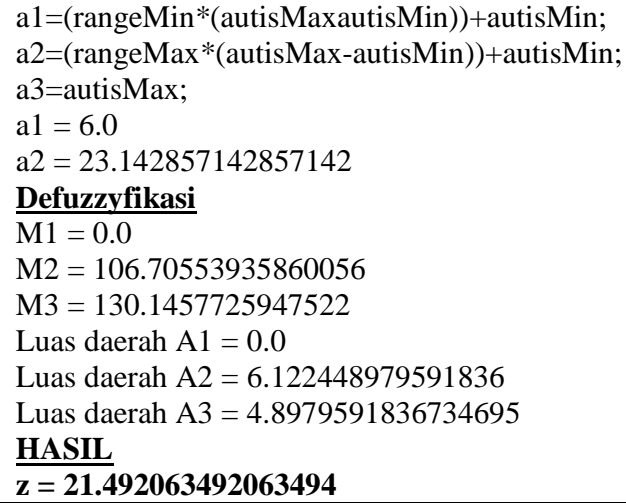

Gambar 5. Proses Fuzzy Mamdani

\subsection{Hasil}

Berdsarkan uji coba data sebanyak 1287 data, diperoleh ketidak sesuaian data hasil fuzzy dengan DSM-IV sebanyak 40 data. Dengan demikian dapat ditentukan recall, precision dan error rate (lihat Tabel 4). Dengan recall sebesar $69 \%$, precision 99\% dan error rate sebesar $3 \%$. Data error dapat dilihat pada Tabel 3.

Table 3. Data error fuzzy mamdani

\begin{tabular}{|c|l|l|l|l|l|l|}
\hline No & I & K & $\mathbf{P}$ & $\mathbf{Z}$ & $\begin{array}{c}\text { Dugaan } \\
\text { Fuzzy }\end{array}$ & DSM-IV \\
\hline 1 & 1 & 5 & 1 & 21.874204807138746 & Autis & Normal \\
\hline 2 & 1 & 5 & 2 & 21.874204807138746 & Autis & Normal \\
\hline 3 & 1 & 5 & 3 & 21.874204807138746 & Autis & Normal \\
\hline 4 & 1 & 5 & 4 & 21.874204807138746 & Autis & Normal \\
\hline 5 & 1 & 5 & 5 & 21.874204807138746 & Autis & Normal \\
\hline 6 & 1 & 5 & 6 & 21.874204807138746 & Autis & Normal \\
\hline 7 & 1 & 5 & 7 & 21.874204807138746 & Autis & Normal \\
\hline 8 & 1 & 5 & 8 & 21.874204807138746 & Autis & Normal \\
\hline 9 & 1 & 6 & 1 & 21.874204807138746 & Autis & Normal \\
\hline 10 & 1 & 6 & 2 & 21.874204807138746 & Autis & Normal \\
\hline 11 & 1 & 6 & 3 & 21.874204807138746 & Autis & Normal \\
\hline 12 & 1 & 6 & 4 & 21.874204807138746 & Autis & Normal \\
\hline 13 & 1 & 6 & 5 & 21.874204807138746 & Autis & Normal \\
\hline 14 & 1 & 6 & 6 & 21.874204807138746 & Autis & Normal \\
\hline 15 & 1 & 6 & 7 & 21.874204807138746 & Autis & Normal \\
\hline 16 & 1 & 6 & 1 & 21.874204807138746 & Autis & Normal \\
\hline 17 & 2 & 1 & 2 & 21.857142857142854 & Autis & Normal \\
\hline 18 & 2 & 1 & 8 & 22.000000000000000 & Normal & Autis \\
\hline 19 & 2 & 2 & 1 & 21.9111111111108 & Autis & Normal \\
\hline 20 & 2 & 10 & 1 & 22.000000000000000 & Normal & Autis \\
\hline 21 & 2 & 10 & 8 & 22.000000000000000 & Normal & Autis \\
\hline 22 & 3 & 1 & 8 & 21.927272727272726 & Normal & Autis \\
\hline 23 & 3 & 10 & 1 & 21.927272727272726 & Normal & Autis \\
\hline 24 & 3 & 10 & 8 & 21.927272727272726 & Normal & Autis \\
\hline 25 & 7 & 0 & 1 & 21.783600194080545 & Autis & Normal \\
\hline 26 & 7 & 0 & 2 & 21.783600194080545 & Autis & Normal \\
\hline 27 & 7 & 0 & 3 & 21.783600194080545 & Autis & Normal \\
\hline 28 & 7 & 0 & 4 & 21.783600194080545 & Autis & Normal \\
\hline 29 & 7 & 0 & 5 & 21.783600194080545 & Autis & Normal \\
\hline 30 & 7 & 0 & 6 & 21.783600194080545 & Autis & Normal \\
\hline 31 & 7 & 0 & 7 & 21.783600194080545 & Autis & Normal \\
\hline 32 & 7 & 0 & 8 & 21.783600194080545 & Autis & Normal \\
\hline 33 & 11 & 1 & 1 & 21.927272727272726 & Normal & Autis \\
\hline 34 & 11 & 1 & 8 & 21.927272727272726 & Normal & Autis \\
\hline
\end{tabular}

\begin{tabular}{|l|l|l|l|l|l|l|}
\hline 35 & 11 & 10 & 1 & 21.927272727272726 & Normal & Autis \\
\hline 36 & 11 & 10 & 8 & 21.927272727272726 & Normal & Autis \\
\hline 37 & 12 & 1 & 1 & 22.000000000000000 & Normal & Autis \\
\hline 38 & 12 & 1 & 8 & 22.000000000000000 & Normal & Autis \\
\hline 39 & 12 & 10 & 1 & 22.000000000000000 & Normal & Autis \\
\hline 40 & 12 & 10 & 8 & 22.000000000000000 & Normal & Autis \\
\hline
\end{tabular}

Tabel 4. Confusion matrix

\begin{tabular}{|c|c|c|c|}
\hline \multicolumn{2}{|c|}{} & \multicolumn{2}{|c|}{ Prediksi Fuzzy } \\
\cline { 3 - 4 } \multicolumn{2}{|c|}{} & $\mathrm{P}$ & $\mathrm{N}$ \\
\hline DSM-IV & $\mathrm{T}$ & 877 & 11 \\
\cline { 2 - 4 } & $\mathrm{F}$ & 11 & 399 \\
\hline
\end{tabular}

\section{KESIMPULAN}

Dari hasil pembahasan, maka dapat disimpulkan bahwa diagnosa Autism Spectrum Disorder (Asd) dapat dilakukan dengan menggunakan fuzzy logic metode mamdani dengan Precision sebesar 99\%, error rate sebanyak $3.11 \%$, dan Recall sebesar $69 \%$.

\section{SARAN}

Tingkat kesalahan perhitungan fuzzy yang relatif kecil dibandingkan dengan DSM-IV, memungkinkan untuk digunakan dalam membantu masyarakat untuk mengetahui gejala autis sejak dini. Konsultasi lebih lanjut kepada pakar ataupun pskiater anak tetap harus dilakukan.

Tingkat kesalahan yang dihasilkan oleh perhitungan fuzzy perlu diperkecil dengan merubah fungsi keanggotaan yang digunakan, penambahan rule, dan rentang parameter yang digunakan.

\section{DAFTAR PUSTAKA}

1. Handojo, Y. 2002. Autisma; Petunjuk Praktis Dan Pedoman Materi Untuk Mengajar Anak Normal, Autis, Dan Perilaku Lain. Surabaya: PT.Bhuana Ilmu Populer.

2. Kusumadewi, Sri. 2003. Artificial Intelligence (Teknik dan Aplikasinya). Yogyakarta: Graha Ilmu

3. Kusumawati, Ririen. 2007. Artificial Intelligence. Menyamai Kecerdasan Buatan Ilahi. Malang: UIN - Malang Press. 
4. Maulana, Mirza. 2007. Anak Autis; Mendidik Anak autis dan Gangguan Mental Lain Menuju Anak Cerdas dan Sehat. Yogyakarta: Katahati.

5. Ning Tan, Pang, Steinbach, Michel and Kumar, Vipin. 2006. Intoduction to Data Mining. United State of America: Pearson Education.

6. Safaria, Triantoro. 2005. Autisme: Pemahaman Baru Untuk Hidup Bermakna Bagi Orang Tua. Yogyakarta: Graha Ilmu. 